University of Nebraska - Lincoln

DigitalCommons@University of Nebraska - Lincoln

Pesticide Occurrence in Selected South Florida Canals and Biscayne Bay during High Agricultural Activity

Jennifer A. Harman-Fetcho

USDA-ARS

Cathleen J. Hapeman

USDA-ARS, cathleen.hapeman@ars.usda.gov

Laura McConnell

USDA-ARS

Thomas L. Potter

USDA-ARS

Clifford P. Rice

USDA-ARS, clifford.rice@ars.usda.gov

See next page for additional authors

Follow this and additional works at: https://digitalcommons.unl.edu/usdaarsfacpub

Harman-Fetcho, Jennifer A.; Hapeman, Cathleen J.; McConnell, Laura; Potter, Thomas L.; Rice, Clifford P.; Sadeghi, Ali M.; Smith, Ramona D.; Bialek, Krystyna; Sefton, Kerry A.; Schaffer, Bruce A.; and Curry, Richard, "Pesticide Occurrence in Selected South Florida Canals and Biscayne Bay during High Agricultural Activity" (2005). Publications from USDA-ARS / UNL Faculty. 1650.

https://digitalcommons.unl.edu/usdaarsfacpub/1650

This Article is brought to you for free and open access by the U.S. Department of Agriculture: Agricultural Research Service, Lincoln, Nebraska at DigitalCommons@University of Nebraska - Lincoln. It has been accepted for inclusion in Publications from USDA-ARS / UNL Faculty by an authorized administrator of DigitalCommons@University of Nebraska - Lincoln. 


\section{Authors}

Jennifer A. Harman-Fetcho, Cathleen J. Hapeman, Laura McConnell, Thomas L. Potter, Clifford P. Rice, Ali M. Sadeghi, Ramona D. Smith, Krystyna Bialek, Kerry A. Sefton, Bruce A. Schaffer, and Richard Curry 


\title{
Pesticide Occurrence in Selected South Florida Canals and Biscayne Bay during High Agricultural Activity
}

\author{
Jennifer A. Harman-Fetcho,${ }^{\dagger}$ Cathleen J. Hapeman, $*, \dagger$ \\ Laura L. McConnell,${ }^{\dagger}$ Thomas L. Potter, ${ }^{\ddagger}$ Clifford P. Rice, ${ }^{\dagger}$ \\ Ali M. Sadeghi, ${ }^{\dagger}$ Ramona D. Smith,${ }^{\dagger}$ Krystyna Bialek, ${ }^{\dagger}$ Kerry A. Sefton ${ }^{\dagger}$ \\ BRUCE A. SCHAFFER, ${ }^{\S}$ AND RichaRd CURRY ${ }^{\#}$ \\ Environmental Quality Laboratory, Agricultural Research Service, U.S. Department of Agriculture, \\ 10300 Baltimore Avenue, Beltsville, Maryland 20705; Southeast Watershed Research Laboratory, \\ Agricultural Research Service, U.S. Department of Agriculture, Tifton, Georgia 31793; \\ Tropical Research and Education Center, University of Florida, Homestead, Florida 33031; and \\ National Park Service, Biscayne National Park, Homestead, Florida 33033
}

\begin{abstract}
Climate and soil conditions in South Florida along with an extensive canal system facilitate movement of agricultural pesticides into surface waters. In a two-year study (2002-2004) of the currently used pesticides in South Florida, atrazine, endosulfan, metolachlor, chlorpyrifos, and chlorothalonil were the most frequently detected in the canals and in Biscayne Bay, with average concentrations of 16 , $11,9.0,2.6$, and $6.0 \mathrm{ng} / \mathrm{L}$, respectively. Concentrations of atrazine and chlorpyrifos were highest near corn production. Chlorothalonil and endosulfan concentrations were highest near vegetable production, with no clear trend for metolachlor, which is used on multiple crops. Concentration data were used to calculate an aquatic life hazard potential for the planting period (November) versus the harvest period (March). This analysis indicated that a higher hazard potential occurs during harvest, primarily from the use of endosulfan. These data will also serve to document canal conditions prior to implementation of the Comprehensive Everglades Restoration Plan (CERP).
\end{abstract}

KEYWORDS: Pesticide; agrochemical; atrazine; endosulfan; chlorothalonil; chlorpyrifos; metolachlor; hazard potential; South Florida; Everglades; Biscayne Bay; Comprehensive Everglades Restoration Plan (CERP)

\section{INTRODUCTION}

The South Florida region is a unique combination of highly productive agricultural lands; residential development from the expanding, Miami urban area; critical terrestrial and aquatic wildlife habitat contained in the Everglades and Biscayne and Florida Bays; and 1000 miles of engineered canal structures for flood control (1). Significant declines in the ecosystem health of the Biscayne and Florida Bays have been reported in the past two decades with the die-off of seagrass beds; declines in sponge, coral, and shellfish populations; and development of noxious algal blooms $(2,3)$. Wildlife populations within the Everglades watershed, especially those of wading birds, have declined since the construction of flood control structures in the 1950s, which efficiently move stormwater into canals rather than allowing for natural flows into the Everglades.

* Author to whom correspondence should be addressed [telephone (301) 504-6511; fax (301) 504-5048; e-mail hapemanc@ba.ars.usda.gov].

Environmental Quality Laboratory, U.S. Department of Agriculture.

$\doteqdot$ Southeast Watershed Research Laboratory, U.S. Department of Agriculture.

$\S$ University of Florida.

\# National Park Service.
Recently, the Comprehensive Everglades Restoration Plan (CERP) was authorized and implementation initiated as part of the Federal Water Resources Development Act of 2000 (4). At an estimated cost of $\$ 15.8$ billion over the next 40 years, water from new reservoirs, wetland-based treatment areas, and underground aquifer storage wells will be redirected into the Everglades to bring the hydrologic system closer to historical levels (1). As part of this plan, stormwater will be retained in an attempt to reduce excess nitrogen, phosphorus, and agrochemicals prior to entering the Everglades. However, only limited information is available on pesticide residues present in these canal waters and their potential toxicity to aquatic organisms. Previous studies in the area around the C-111 canal have shown that exposure to the insecticide endosulfan may be causing chronic toxic effects in copepods, clams, and oysters (5), and organophosphate insecticides were suspected of causing acetylcholinesterase inhibition in grass shrimp collected in two South Florida canals (6).

The climate and hydrologic conditions in South Florida are different from those of other major agricultural centers in the United States, thereby limiting the usefulness of previous pesticide fate research data. These conditions include calcareous 


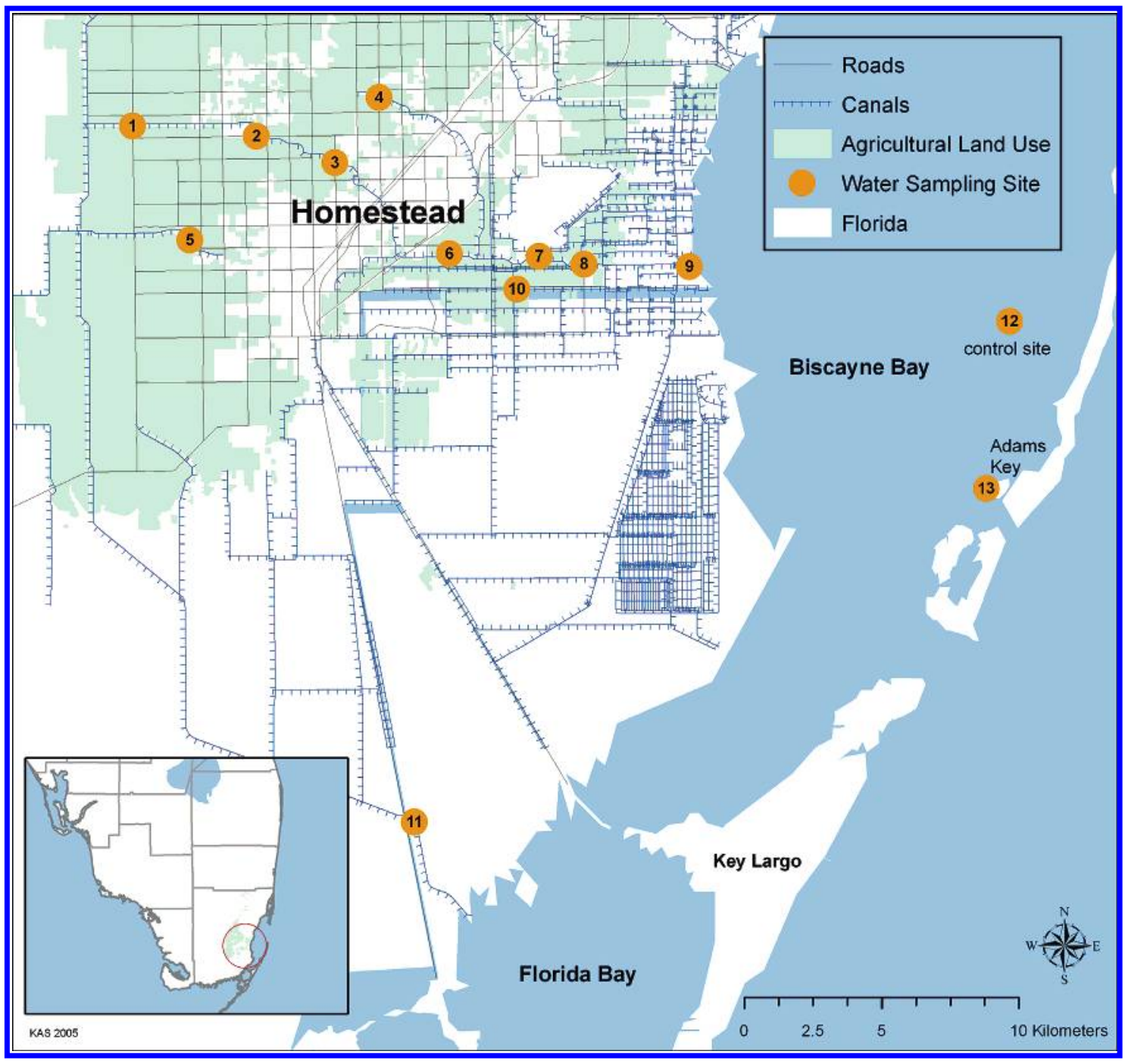

Figure 1. Water sample collection sites in South Florida.

soils, frequent rainfall, high humidity, high temperatures, and a highly transmissive aquifer system. Soils in South Florida's Dade County range from peat and muck in the northwest to medium and fine sand in the central and southeast (7). In some areas soils consist of porous limestone, and cultivated soils represent a thin layer of low-moisture naturally weathered or mechanically crushed limerock (8). The surficial aquifer, called the Biscayne aquifer, has a high transmissivity of $\sim 28000 \mathrm{~m}^{2} /$ day in central and eastern Dade County with a high potential for leaching both nutrients and pesticides. Other areas in the west have lower transmissivities of $\sim 7000 \mathrm{~m}^{2} /$ day (7). The low water-holding capacity of some South Florida soils and high temperatures also necessitate frequent irrigation of crops, thereby enhancing leaching of agrochemicals. During the dry season, groundwater discharge feeds the canal system, and canal flows feed into Biscayne and Florida Bays and into the Everglades, where sensitive aquatic biota may be affected.

The goals of this study were to determine the types and concentrations of currently used pesticides present in water from several South Florida canals and Biscayne Bay, to examine the impact of land use categories as sources of particular chemicals, and to provide a preliminary assessment of the potential toxicity of the most frequently detected pesticides. To meet these goals, samples were collected during time periods of highest agricultural activity from October to March. This current work was performed prior to the implementation of the CERP. Therefore, these data can be used as a benchmark for comparison with future measurements after major changes in water quality management in the area. These data will also be useful for regulators, extension specialists, and decision-makers in designing and modifying agricultural management practices to better protect sensitive ecosystems.

\section{MATERIALS AND METHODS}

Water Sampling. Thirteen water collection sites were selected in the Homestead, FL, area of South Miami-Dade County, 35 miles south of Miami (Figure 1). Water samples were collected during seven sampling trips on November 13-15, 2002; January 7-9, 2003; March 10-12, 2003; November 10-12, 2003; January 4-6, 2004; February 15-17, 2004; and March 25-27, 2004. A total of 91 water samples were collected (3 samples were lost during the processing steps).

Water was collected from a depth of $1 \mathrm{~m}$ using an $1100 \mathrm{GPH}$ submersible marine pump (Rule Industries, Gloucester, MA). The pump was connected directly to two, in-line, high-pressure, stainless steel filter holders (Millipore, Bedford, MA) housing a $2.7 \mu \mathrm{m}$ pore size GF/D glass fiber prefilter (Whatman, Middlesex, U.K.) and a $0.7 \mu \mathrm{m}$ pore size GF/F filter (Whatman), respectively, with Teflon and stainless steel tubing. Using a $2 \mathrm{~L}$ graduated cylinder, exactly $10 \mathrm{~L}$ of filtered sample water was collected in a precleaned, $20 \mathrm{~L}$, stainless steel canister (Pepsi, Hyattsville, MD) with an airtight lid and stored on ice until processing $(\leq 12 \mathrm{~h})$. Water quality measurements including $\mathrm{pH}$, salinity, conductivity, dissolved oxygen, and water temperature were recorded at each sample site (Table 1) using a precalibrated, multifunctional, portable probe (model 556 MPS, YSI Environmental, Yellow Springs, $\mathrm{OH})$. 
Table 1. Average Measurements of Water Temperature, $\mathrm{pH}$, Dissolved Oxygen, and Salinity between November 2002 and March $2004(n=$ 6) ${ }^{a}$ for 13 Sampling Sites in South Florida

\begin{tabular}{|c|c|c|c|c|c|}
\hline site & coordinates & temp $\left({ }^{\circ} \mathrm{C}\right)$ & $\mathrm{pH}$ & $\begin{array}{c}\text { salinity } \\
\text { TDS } \\
(\mathrm{g} / \mathrm{L})\end{array}$ & $\begin{array}{l}\text { dissolved } \\
\text { oxygen } \\
\text { (mg/L) }\end{array}$ \\
\hline 1 & $\begin{array}{l}25^{\circ} 31^{\prime} 1.54^{\prime \prime} \mathrm{N} \\
80^{\circ} 32^{\prime} 34.05^{\prime \prime} \mathrm{W}\end{array}$ & $23.7 \pm 1.6$ & $6.9 \pm 0.6$ & $0.4 \pm 0.1$ & $3.2 \pm 1.0$ \\
\hline 2 & $\begin{array}{l}25^{\circ} 30^{\prime} 49.03^{\prime \prime} \mathrm{N} \\
80^{\circ} 29^{\prime} 52.73^{\prime \prime} \mathrm{W}\end{array}$ & $23.8 \pm 1.4$ & $7.1 \pm 0.6$ & $0.4 \pm 0.1$ & $3.5 \pm 1.0$ \\
\hline 3 & $\begin{array}{l}25^{\circ} 30^{\prime} 17.19^{\prime \prime} \mathrm{N} \\
80^{\circ} 28^{\prime} 10.10^{\prime \prime} \mathrm{W}\end{array}$ & $23.6 \pm 1.9$ & $7.3 \pm 0.6$ & $0.4 \pm 0.1$ & $5.8 \pm 1.0$ \\
\hline 4 & $\begin{array}{l}25^{\circ} 31^{\prime} 33.85^{\prime \prime} \mathrm{N} \\
80^{\circ} 27^{\prime} 12.50^{\prime \prime} \mathrm{W}\end{array}$ & $24.3 \pm 0.9$ & $7.1 \pm 0.5$ & $0.5 \pm 0.1$ & $3.6 \pm 0.5$ \\
\hline 5 & $\begin{array}{l}25^{\circ} 28^{\prime} 46.25^{\prime \prime} \mathrm{N} \\
80^{\circ} 31^{\prime} 19.53^{\prime \prime} \mathrm{W}\end{array}$ & $24.1 \pm 2.0$ & $7.0 \pm 0.7$ & $0.4 \pm 0.1$ & $2.9 \pm 1.1$ \\
\hline 6 & $\begin{array}{l}25^{\circ} 28^{\prime} 28.79^{\prime \prime} \mathrm{N} \\
80^{\circ} 25^{\prime} 41.54^{\prime \prime} \mathrm{W}\end{array}$ & $24.1 \pm 1.3$ & $7.3 \pm 0.6$ & $0.5 \pm 0.1$ & $5.4 \pm 2.1$ \\
\hline 7 & $\begin{array}{l}25^{\circ} 28^{\prime} 25.18^{\prime \prime} \mathrm{N} \\
80^{\circ} 23^{\prime} 44.71^{\prime \prime} \mathrm{W}\end{array}$ & $23.9 \pm 1.5$ & $7.5 \pm 0.5$ & $0.4 \pm 0.1$ & $5.4 \pm 0.7$ \\
\hline 8 & $\begin{array}{l}25^{\circ} 28^{\prime} 16.01^{\prime \prime} \mathrm{N} \\
80^{\circ} 22^{\prime} 46.31^{\prime \prime} \mathrm{W}\end{array}$ & $24.2 \pm 1.4$ & $7.3 \pm 0.7$ & $0.6 \pm 0.2$ & $5.8 \pm 1.1$ \\
\hline 9 & $\begin{array}{l}25^{\circ} 28^{\prime} 12.42^{\prime \prime} \mathrm{N} \\
80^{\circ} 20^{\prime} 28.76^{\prime \prime} \mathrm{W}\end{array}$ & $23.0 \pm 2.7$ & $7.5 \pm 0.8$ & $24 \pm 10$ & $6.0 \pm 1.1$ \\
\hline 10 & $\begin{array}{l}25^{\circ} 27^{\prime} 46.56^{\prime \prime} \mathrm{N} \\
80^{\circ} 24^{\prime} 13.72^{\prime \prime} \mathrm{W}\end{array}$ & $23.5 \pm 1.9$ & $7.3 \pm 0.8$ & $0.4 \pm 0.1$ & $5.7 \pm 2.0$ \\
\hline 11 & $\begin{array}{l}25^{\circ} 17^{\prime} 16.54^{\prime \prime} \mathrm{N} \\
80^{\circ} 26^{\prime} 30.18^{\prime \prime} \mathrm{W}\end{array}$ & $23.6 \pm 1.9$ & $7.5 \pm 0.9$ & $0.6 \pm 0.4$ & $6.2 \pm 1.0$ \\
\hline 12 & $\begin{array}{l}25^{\circ} 27^{\prime} 5.71^{\prime \prime} \mathrm{N} \\
80^{\circ} 13^{\prime} 30.95^{\prime \prime} \mathrm{W}\end{array}$ & $22.3 \pm 3.4$ & $7.8 \pm 0.6$ & $37 \pm 7.7$ & $6.3 \pm 1.6$ \\
\hline 13 & $\begin{array}{l}25^{\circ} 23^{\prime} 48.54^{\prime \prime} \mathrm{N} \\
80^{\circ} 14^{\prime} 3.01^{\prime \prime} \mathrm{W}\end{array}$ & $22.3 \pm 3.2$ & $7.9 \pm 0.5$ & $38 \pm 7.3$ & $6.1 \pm 1.5$ \\
\hline
\end{tabular}

a Data from March 2003 are unavailable.

Sample collection equipment was cleaned between stations by pumping several liters of a 1:1 organic-free water/methanol mixture through the entire filtration system to avoid cross-contamination. Field blanks were collected by pumping $10 \mathrm{~L}$ of organic-free water through the sampling and filtration system into a clean stainless steel canister to evaluate the equipment for contamination. Replicate samples were collected at sites 11 and 12 with each set of samples for use as matrix spike recovery samples. Two field blanks and two matrix spike recovery samples were collected on each of the seven sampling trips. Duplicate samples were also collected periodically from randomly selected sites to evaluate the precision of the method.

Extraction Method. Prior to extraction, all samples were fortified with an extraction efficiency surrogate standard, diazinon [diethyl- $d_{10}$ ] (Cambridge Isotope Laboratories, Andover, MA). Each $10 \mathrm{~L}$ sample was then drawn by vacuum through a solid-phase extraction (SPE) cartridge containing $500 \mathrm{mg}$ of hyper-cross-linked styrene-divinylbenzene copolymer, ENV+ (Argonaut, Inc., Redwood City, CA), extraction resin. After extraction, ENV + cartridges were dried with high-purity nitrogen gas and eluted with chromatographic grade solvents ( $6 \mathrm{~mL}$ of dichloromethane followed by $9 \mathrm{~mL}$ of $3: 1$ acetone/acetonitrile) (Fisher Scientific, Fair Lawn, NJ). The $15 \mathrm{~mL}$ extract was concentrated to a final volume of $0.5 \mathrm{~mL}$ under high-purity nitrogen. Internal standards, atrazine [ethylamine- $d_{5}$ ] (Cambridge Isotope Laboratories) and PCB-204 (2,2',3,4,4',5,6,6'-octachlorobiphenyl) (AccuStandard, New Haven CT), were added to the final sample extracts and standards.

Analytical Methodology. Sample extracts were analyzed by gas chromatography-mass spectrometry (GC-MS). Target compounds, instrument mode, ions of interest, minimum detection limits (MDL), detected concentration ranges, percent detection, and spike recovery values are listed in Table 2. Full-scan spectra were acquired using a Varian 3800 GC coupled to a Saturn 2000 Ion Trap MS equipped with a DB-17MS (Agilent Technologies, Inc., Palo Alto, CA) 30 m, 0.25 $\mathrm{mm}$ i.d., $0.25 \mu \mathrm{m}$ in film thickness capillary column. The GC inlet was operated in splitless mode. The carrier gas was ultrahigh-purity helium at a constant flow rate of $1.0 \mathrm{~mL} / \mathrm{min}$ controlled by a constant flow-pressure program. Operational temperatures were as follows: injection port, $260{ }^{\circ} \mathrm{C}$; oven, $130{ }^{\circ} \mathrm{C}(1 \mathrm{~min})$, ramped at $5^{\circ} \mathrm{C} / \mathrm{min}$ to $280{ }^{\circ} \mathrm{C}$; interface, $280{ }^{\circ} \mathrm{C}$; and ion trap, $220^{\circ} \mathrm{C}$. The ion trap MS was operated in electron impact (EI)-selective ion storage (SIS) mode, scanning for ions with masses of 70-450.

Better sensitivity for halogenated analytes was achieved using a Hewlett-Packard (HP) 5890 GC coupled to a HP 5989A quadrapole MS in the negative chemical ionization (NCI) mode. The GC inlet was operated in splitless mode with a column identical to that used on the Varian GC-MS. The carrier gas was ultrahigh-purity helium at a constant flow rate of $1.12 \mathrm{~mL} / \mathrm{min}$ controlled by a constant flowpressure program. Operational temperatures were as follows: injection port, $280{ }^{\circ} \mathrm{C}$; oven, $130{ }^{\circ} \mathrm{C}(1 \mathrm{~min})$, ramped at $6{ }^{\circ} \mathrm{C} / \mathrm{min}$ to $280{ }^{\circ} \mathrm{C}$; interface, $280{ }^{\circ} \mathrm{C}$; source, $150{ }^{\circ} \mathrm{C}$; quadrupole, $100{ }^{\circ} \mathrm{C}$. NCI reagent gas was methane, and the source pressure was 1.6 Torr.

The instruments were calibrated using a mixture of analytes with at least five different concentrations across the expected sample range. Calibration curves were repeated for every 20 sample injections. Sample results were quantified using the internal standard method. In laboratory experiments utilizing fortified organic carbon free water, the extraction method has proven to be efficient at isolating our target compounds (9). Using this same extraction method $(10),>80 \%(n=11)$ of spiked pesticides were recovered from $10 \mathrm{~L}$ water samples. Results for spike recovery samples collected on each sampling trip $(n=14)$ averaged $>80 \%$ recovery for the majority of target compounds listed in Table 2. Aldrin, fipronil, and $p, p^{\prime}$-DDE were slightly lower (76, 79, and 70\%, respectively), but were still within the acceptable range set forth by EPA standard methods (11). Field blank samples $(n=14)$ were devoid of compounds at levels greater than our minimal detection limits. Recovery of the surrogate compound diazinon [diethyl- $d_{10}$ ] was measured in all sample extracts, blanks, spikes, and replicates with acceptable values $(>82 \pm 7 \%, n=114)$.

\section{RESULTS}

In South Florida, pesticides are used intensively for crop protection, mosquito control, and landscape management. U.S. Department of Agriculture (USDA) surveys indicate that in the 16 county region served by the South Florida Water Management District, agriculture accounts for the application of nearly 20 million pounds of pesticide active ingredients (12). Agricultural production in the region is extremely heterogeneous, ranging from numerous vegetable crops, that is, bush and pole beans, tomatoes, squash, okra, peppers, to sweet corn, cabbage, eggplant, potatoes, strawberries, herbs, and ornamental plants (13). This area is sometimes referred to as the nation's "Salad Bowl" (14).

The 13 sites in the study area were chosen because of the high agricultural activity and close proximity to sensitive ecosystems of both Everglades National Park and Biscayne National Park (Figure 1). Sites 5 and 10 are located in areas with high agricultural land usage, and site 11 is located to the south, on the C-111 canal, which drains much of the northern agricultural area. Eight sites (1-4 and 6-9) occur along the Mowry canal, which runs through mixed-use areas (agricultural and urban) and empties ultimately into Biscayne Bay. Site 12, located in the middle of Biscayne Bay, is the control site with minimal direct land influence. Site 13 is adjacent to Adams Key, a small remote island that is part of the National Park system.

A narrow range of temperatures was observed in the canals and Biscayne Bay $\left(22-24{ }^{\circ} \mathrm{C}\right)$ over the course of the study, although sampling was not carried out during the summer months (Table 1). Water from the canal sites was essentially fresh, with salinity values close to zero except for site 9 , at the mouth of the Mowry canal (mean salinity $=24$ ), and higher 
Table 2. Quantification Parameters, Quality Assurance Results, and Percent Detection Results Summary for Water Samples Collected in South Florida

\begin{tabular}{|c|c|c|c|c|c|c|}
\hline target compound & $\begin{array}{l}\text { instrument } \\
\text { mode }^{a}\end{array}$ & $\begin{array}{c}\text { mass ions } \\
\text { monitored }(\mathrm{m} / \mathrm{z})\end{array}$ & $\begin{array}{l}\mathrm{MDL}^{b} \\
\text { (ng/L) }\end{array}$ & $\begin{array}{c}\text { recovery (\%) } \\
n=14^{c}\end{array}$ & $\begin{array}{c}\text { concn range }{ }^{d} \\
(\mathrm{ng} / \mathrm{L})\end{array}$ & $\begin{array}{c}\text { detection (\%) } \\
n=88\end{array}$ \\
\hline acetochlor & El & $162,174,223,225$ & 1.5 & $92 \pm 10$ & & 0 \\
\hline alachlor & $\mathrm{El}$ & 160,188 & 1.4 & $91 \pm 9$ & & 0 \\
\hline aldrin & $\mathrm{NCl}$ & $237,330,332$ & 0.2 & $76 \pm 20$ & $0.38-1.1$ & 6 \\
\hline ametryn & $\mathrm{El}$ & $212,227,229$ & 1.4 & $88 \pm 18$ & & 0 \\
\hline atrazine & $\mathrm{El}$ & $173,200,215$ & 0.9 & $105 \pm 13$ & $0.90-108$ & 91 \\
\hline chlorothalonil & $\mathrm{NCl}$ & $264,266,268$ & 0.2 & $84 \pm 33$ & $0.27-14$ & 82 \\
\hline$\alpha$-chlordane & $\mathrm{NCl}$ & $408,410,412$ & 0.2 & $87 \pm 15$ & $0.21-3.1$ & 9 \\
\hline$\gamma$-chlordane & $\mathrm{NCl}$ & $408,410,412$ & 0.2 & $87 \pm 14$ & $0.40-1.1$ & 2 \\
\hline chlorpyrifos & $\mathrm{NCl}$ & $214,313,315$ & 0.2 & $124 \pm 36$ & $0.20-58$ & 66 \\
\hline cyanazine & El & $198,212,225$ & 1.8 & $89 \pm 11$ & & 0 \\
\hline$p, p-D D D$ & $\mathrm{NCl}$ & $248,250,320$ & 0.2 & $86 \pm 40$ & $0.95-9.0$ & 6 \\
\hline$p, p-D D E$ & $\mathrm{NCl}$ & $281,316,318,320$ & 0.2 & $70 \pm 12$ & $0.4-2.4$ & 7 \\
\hline$p, p$-DDT & $\mathrm{NCl}$ & $71,248,318$ & 0.2 & $86 \pm 29$ & $2.1-10$ & 5 \\
\hline diazinon & $\mathrm{NCl}$ & 169,303 & 1.0 & $107 \pm 37$ & $1.0-7.1$ & 19 \\
\hline$p, p$-dicofol & $\mathrm{El}$ & 111,139 & 1.5 & $83 \pm 8$ & & 0 \\
\hline dieldrin & $\mathrm{NCl}$ & $237,346,380$ & 0.2 & $230 \pm 121$ & $0.20-4.0$ & 16 \\
\hline$\alpha$-endosulfan & $\mathrm{NCl}$ & $406,408,410$ & 0.2 & $113 \pm 21$ & $0.21-54$ & 81 \\
\hline$\beta$-endosulfan & $\mathrm{NCl}$ & $404,406,408$ & 0.2 & $124 \pm 23$ & $0.20-16$ & 75 \\
\hline endosulfan sulfate & $\mathrm{NCl}$ & $384,386,388$ & 0.2 & $120 \pm 15$ & $0.22-28$ & 91 \\
\hline ethion & El & $203,231,338$ & 1.5 & $87 \pm 7$ & & 0 \\
\hline ethoprop & El & 127,158 & 1.5 & $92 \pm 13$ & & 0 \\
\hline fipronil & $\mathrm{NCl}$ & $331,384,400$ & 0.2 & $79 \pm 15$ & $0.60-8.6$ & 6 \\
\hline$\alpha-\mathrm{HCH}$ & $\mathrm{NCl}$ & $71,255,257$ & 0.2 & $90 \pm 23$ & $0.23-1.3$ & 11 \\
\hline$\gamma-\mathrm{HCH}$ & $\mathrm{NCl}$ & $71,255,257$ & 0.2 & $95 \pm 17$ & $0.20-5.0$ & 6 \\
\hline heptachlor & $\mathrm{NCl}$ & $266,300,232$ & 0.2 & $102 \pm 38$ & $0.28-7.0$ & 16 \\
\hline heptachlor epoxide & $\mathrm{NCl}$ & $237,282,318,388$ & 0.2 & $107 \pm 13$ & $0.31-1.5$ & 5 \\
\hline malathion & $\mathrm{NCl}$ & 157,172 & 1.6 & $121 \pm 36$ & 6.0 & 1 \\
\hline metalaxyl & El & $190,192,206$ & 1.6 & $93 \pm 15$ & & 0 \\
\hline methoxychlor & $\mathrm{El}$ & $114,152,228,344$ & 1.8 & $91 \pm 11$ & & 0 \\
\hline metolachlor & $\mathrm{El}$ & 162,238 & 1.0 & $96 \pm 9$ & $1.1-86$ & 89 \\
\hline metribuzin & El & 198 & 1.5 & $87 \pm 11$ & $0.30-78$ & 8 \\
\hline mirex & $\mathrm{NCl}$ & $334,370,404,439$ & 0.2 & $80 \pm 20$ & $0.25-1.9$ & 3 \\
\hline cis-nonachlor & $\mathrm{NCl}$ & $442,444,446$ & 0.2 & $91 \pm 15$ & & 0 \\
\hline trans-nonachlor & $\mathrm{NCl}$ & $442,444,446$ & 0.2 & $88 \pm 18$ & & 0 \\
\hline oxychlordane & $\mathrm{NCl}$ & $316,350,352,424$ & 0.2 & $89 \pm 18$ & $0.6-0.7$ & 2 \\
\hline pendamethalin & $\mathrm{El}$ & 252 & 1.6 & $90 \pm 9$ & & 0 \\
\hline phorate & $\mathrm{El}$ & 121,231 & 1.5 & $85 \pm 11$ & & 0 \\
\hline simazine & $\mathrm{El}$ & 138, 186, 201 & 1.6 & $101 \pm 12$ & $1.7-16$ & 15 \\
\hline trifluralin & $\mathrm{NCl}$ & $305,335,336$ & 0.2 & $80 \pm 27$ & $0.23-3.6$ & 9 \\
\hline diazinon diethyl- $d_{10}$ & $\mathrm{NCl}$ & 179 & $e$ & $91 \pm 5$ & $e$ & 100 \\
\hline atrazine ethylamine- $d_{5}$ & $\mathrm{El}$ & 205,220 & $f$ & $f$ & $f$ & $f$ \\
\hline PCB-204 & $\mathrm{NCl}$ & $394,428,430$ & $f$ & $f$ & $f$ & $f$ \\
\hline
\end{tabular}

${ }^{a} \mathrm{El}$, electron impact; $\mathrm{NCl}$, negative chemical ionization. ${ }^{b} \mathrm{MDL}$, method detection limit. ${ }^{c}$ Percent spike recovery from surface water samples. ${ }^{d}$ Concentration range represents results for samples where levels were above the minimum detection limit. ${ }^{e}$ Diazinon- $d_{10}$ was used as an extraction efficiency surrogate in each sample, and MDL values were not determined. ${ }^{f}$ Atrazine- $d_{5}$ and PCB-204 were used as internal standards, and MDL values were not determined.

salinity values at the Biscayne Bay sites (mean salinity values $=37-38$ ). The $\mathrm{pH}$ of the canals ranged from 6.3 furthest inland to 8.2 at the more saline Mowry Canal mouth (site 9). As expected, the $\mathrm{pH}$ of the Biscayne Bay sites was $~ 7.8$. Average dissolved oxygen measurements were lowest at the most inland sites and ranged from 37 to $84 \%$.

Summary of Pesticide Concentrations. Target analytes included the pesticides most frequently used in this area (excluding methyl bromide and copper hydroxide) and some persistent, banned pesticides. Results for the 88 water samples analyzed during the growing seasons from 2002 to 2004 indicated that several target compounds (acetochlor, alachlor, ametryn, cyanazine, $p, p$-dicofol, ethion, ethoprop, metalaxyl, methoxychlor, cis- and trans-nonachlor, pendamethalin, and phorate) were never present at concentration levels above the limits of detection (Table 2). Fifteen of the target compounds (aldrin, $\alpha$-chlordane, $\gamma$-chlordane, $p, p$-DDD, $p, p$-DDE, $p, p$-DDT, fipronil, $\alpha-\mathrm{HCH}, \gamma-\mathrm{HCH}$, heptachlor epoxide, malathion, metribuzin, mirex, and trifluralin) were present at detectable concentrations in fewer than $11 \%$ of the 88 samples analyzed. Diazinon, dieldrin, heptachlor, and simazine were present in fewer than $19 \%$ of the water samples. Atrazine, metolachlor, chlorothalonil, chlorpyrifos, and total endosulfan ( $\alpha$-endosulfan $+\beta$-endosulfan + endosulfan sulfate) were detected in greater than $66 \%$ of all samples analyzed. These chemicals will be used in the remaining sections to assess trends, sources, and potential toxicity to aquatic organisms.

Atrazine had the highest observed concentration of any of the target analytes at $108 \mathrm{ng} / \mathrm{L}$, well below the EPA maximum allowable contamination level (MCL) (3000 ng/L). Total endosulfans had a maximum concentration of $98 \mathrm{ng} / \mathrm{L}$ followed by metolachlor at $86 \mathrm{ng} / \mathrm{L}$, chlorpyrifos (58 ng/L), and chlorothalonil (14 ng/L). No MCL values exist for the other compounds of interest; however, the World Health Organization has published acceptable daily intake (ADI) levels for chlorpyrifos, chlorothalonil, and endosulfan of $0.01,0.03$, and 0.006 $\mathrm{mg} / \mathrm{kg} /$ day, respectively (15). For comparison, Table 3 lists the $\mathrm{LC}_{50}(96 \mathrm{~h})$ for freshwater fish. The mean and median concentrations for these five chemicals were all below $20 \mathrm{ng} / \mathrm{L}$ (Figure 2). Examining concentration results for these five chemicals across all stations reveals a large amount of variability 
Table 3. Comparison of Pesticide Concentration Measurements in South Florida Canals from 1992 to 2004 with Corresponding Toxicity Data

\begin{tabular}{|c|c|c|c|c|c|c|}
\hline \multirow[b]{2}{*}{ study reference } & \multirow[b]{2}{*}{ dates } & \multicolumn{5}{|c|}{ concn range (ng/L) } \\
\hline & & atrazine & chlorpyrifos & chlorothalonil & endosulfans & metolachlor \\
\hline $\begin{array}{l}\text { Pfeuffer and Rand (16) } \\
\text { Scott et al. }(5)^{b} \\
\text { Key et al. (6) } \\
\text { Pfeuffer and Matson (17-20) } \\
\text { current study }\end{array}$ & $\begin{array}{l}\text { 1992-2001 } \\
\text { 1993-1997 } \\
\text { Dec 1999 } \\
\text { Nov 2002-May 2003 } \\
\text { Nov 2002-March 2004 }\end{array}$ & $\begin{array}{c}9.9-400 \\
1.0-48 \\
7.9-29.4 \\
10-56 \\
0.90-108\end{array}$ & $\begin{array}{l}-a \\
0.1-2.42 \\
5.2 \\
- \\
0.20-58\end{array}$ & $\begin{array}{l}- \\
0.4-2.70 \\
- \\
- \\
0.27-14\end{array}$ & $\begin{array}{l}103-748 \\
0.2-477 \\
- \\
12-168 \\
0.22-17\end{array}$ & $\begin{array}{l}- \\
-^{c} \\
2.5-119 \\
- \\
1.1-86\end{array}$ \\
\hline $\begin{array}{l}\mathrm{LC}_{50}(96 \mathrm{~h}) \mathrm{fc} \\
\text { hazard rating } \mathrm{c}\end{array}$ & $\begin{array}{l}\text { ow trout } \\
\text { nt }(25,26)\end{array}$ & $\begin{array}{c}\text { toxicity } \\
5.3 \mathrm{e}^{6}(27) \\
0.09\end{array}$ & $\begin{array}{l}g / L) \\
1.8 e^{3 d}(28) \\
7.18\end{array}$ & $\begin{array}{l}4.23 e^{6}(24) \\
2.60\end{array}$ & $\begin{array}{l}800(29) \\
42.8\end{array}$ & $\begin{array}{l}3.9 e^{6 d}(30) \\
0.11\end{array}$ \\
\hline
\end{tabular}

${ }^{a}$ No data reported above the limit of detection values. ${ }^{b}$ Lower range limit is equal to reported method detection limits. ${ }^{c}$ Compound not measured in this study. ${ }^{d} \mathrm{LC}_{50}$ $(96 \mathrm{~h})$ for freshwater fish; species not specified.

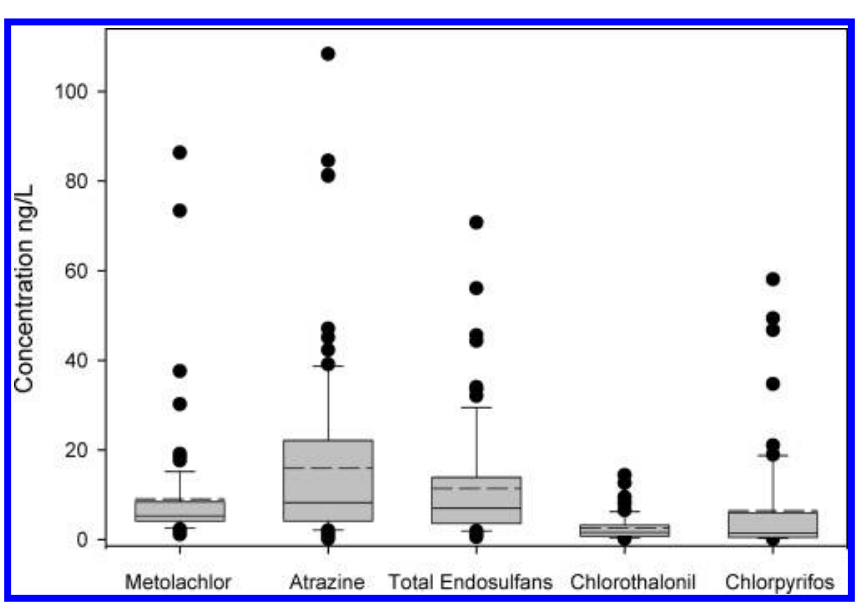

Figure 2. Data summary of atrazine, chlorpyrifos, chlorothalonil, total endosulfans, and metolachlor for all 88 samples analyzed over the course of the study. Medians and means are indicated by the solid and dashed lines, respectively. Boxes indicate the 25th-75th percentiles, whiskers show the 10th and 90th percentiles, and outliers are indicated by dots.

with many outliers above the 90th percentile, suggesting a recent, local pesticide application.

\section{DISCUSSION}

Concentration results from this study compare well with results from other researchers (Table 3). As part of the South Florida Water Management District's (SFWMD) water quality monitoring program (16-20), grab samples have been collected quarterly since 1992 at 34 sites and analyzed for nearly 70 pesticides. The sample volumes were not listed in the reports nor were specific details of the analytical methods. Results for the SFWMD study sites in South Dade County indicated the presence of atrazine and endosulfans with concentrations ranging from 9.9 to $400 \mathrm{ng} / \mathrm{L}$ and from 103 to $748 \mathrm{ng} / \mathrm{L}$, respectively, during the time period from 1992 to 2001 (16). Lower concentrations were found during 2002 and 2003, 10-56 and 12-168 ng/L, respectively (17-20), suggesting a possible decrease in application of these two chemicals in the area. Neither chlorpyrifos, chlorothalonil, nor metolachlor was detected during the entire monitoring period. The maximum concentrations for atrazine and endosulfans for the 2002 and 2003 SFWMD study fall within a factor of $\sim 2$ of those observed in our study.

In a multiyear study of the C-111 canal system of South Florida from 1993 to 1997, observed concentrations of atrazine, chlorpyrifos, chlorothalonil, and endosulfans in water samples ranged from 1 to $48 \mathrm{ng} / \mathrm{L}$, from 0.1 to $2.4 \mathrm{ng} / \mathrm{L}$, from 0.4 to 2.7 $\mathrm{ng} / \mathrm{L}$, and from 0.2 to $477 \mathrm{ng} / \mathrm{L}$, respectively (5). A comparison

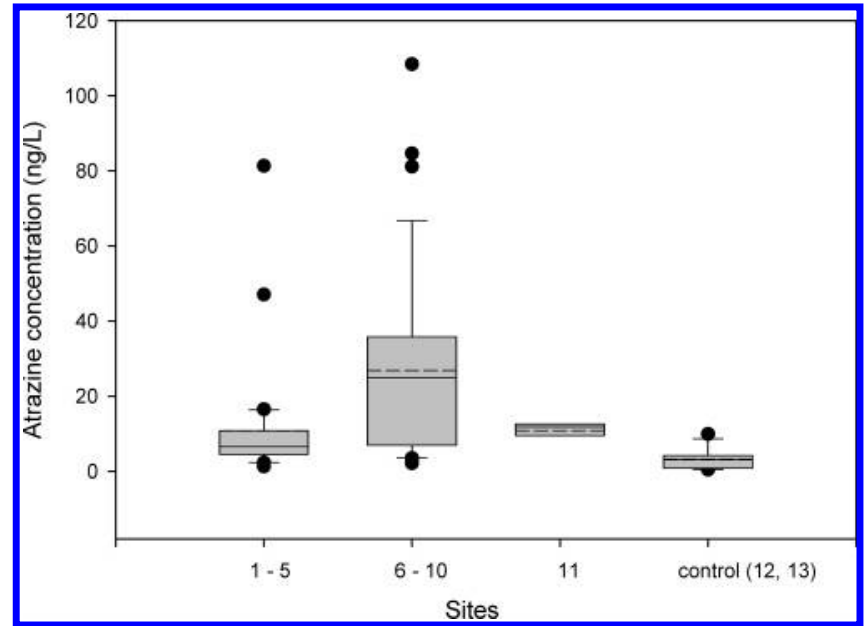

Figure 3. Spatial dependence of atrazine concentrations using all sampling events. Corn is principally grown near sites $6-10$. Medians and means are indicated by the solid and dashed lines, respectively. Boxes indicate the 25th-75th percentiles, whiskers show the 10th and 90th percentiles, and outliers are indicated by dots.

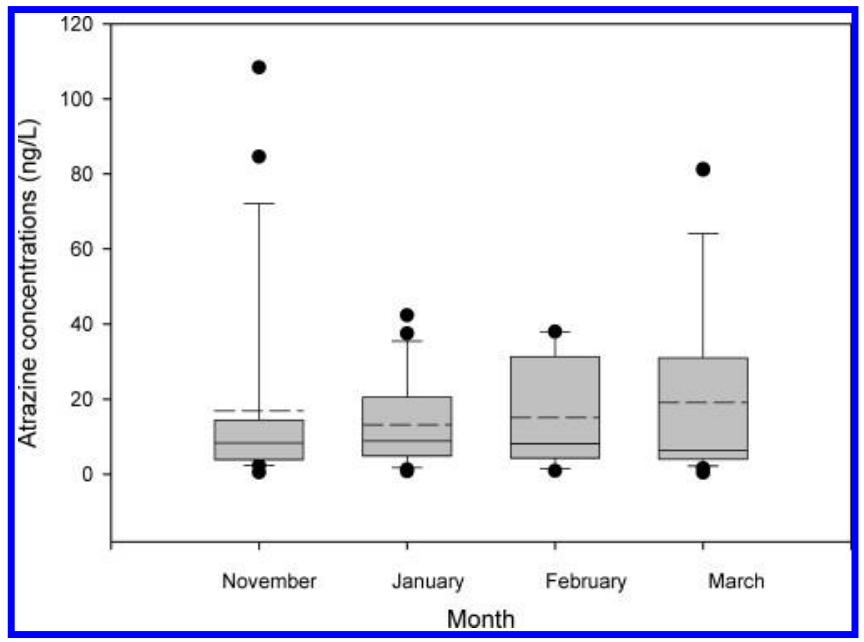

Figure 4. Temporal variation in atrazine concentration using data from all sites. Medians and means are indicated by the solid and dashed lines, respectively. Boxes indicate the 25th-75th percentiles, whiskers show the 10th and 90th percentiles, and outliers are indicated by dots.

of this SFWMD study with the current study also suggests that the use of endosulfan may have decreased since the late 1990s. This observation is supported by data from a 2002 MiamiDade County agricultural land retention study conducted by the University of Florida's Agricultural Market Research Center (21), which states that tomato acreage and production have 


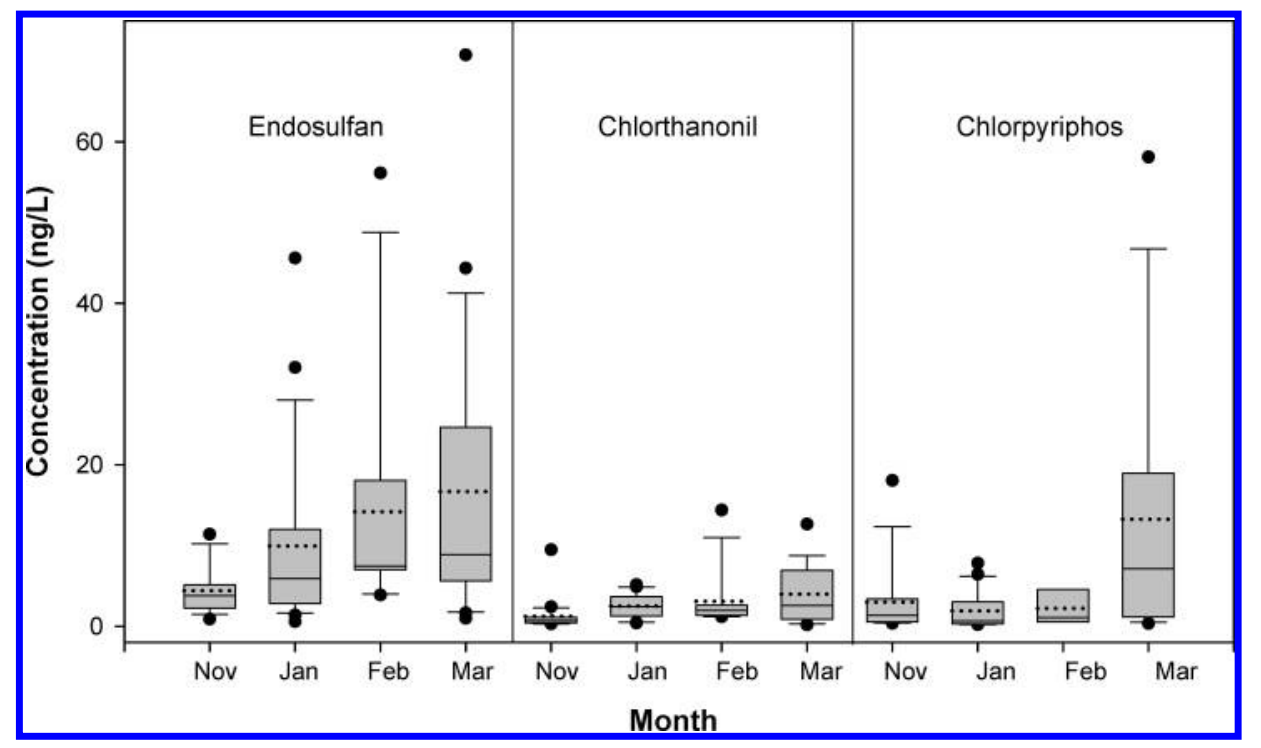

Figure 5. Temporal variation of endosulfan, chlorothalonil, and chlorpyrifos concentrations using data from all locations. Medians and means are indicated by the solid and dotted lines, respectively. Boxes indicate the 25th-75th percentiles, whiskers show the 10th and 90th percentiles, and outliers are indicated by dots.

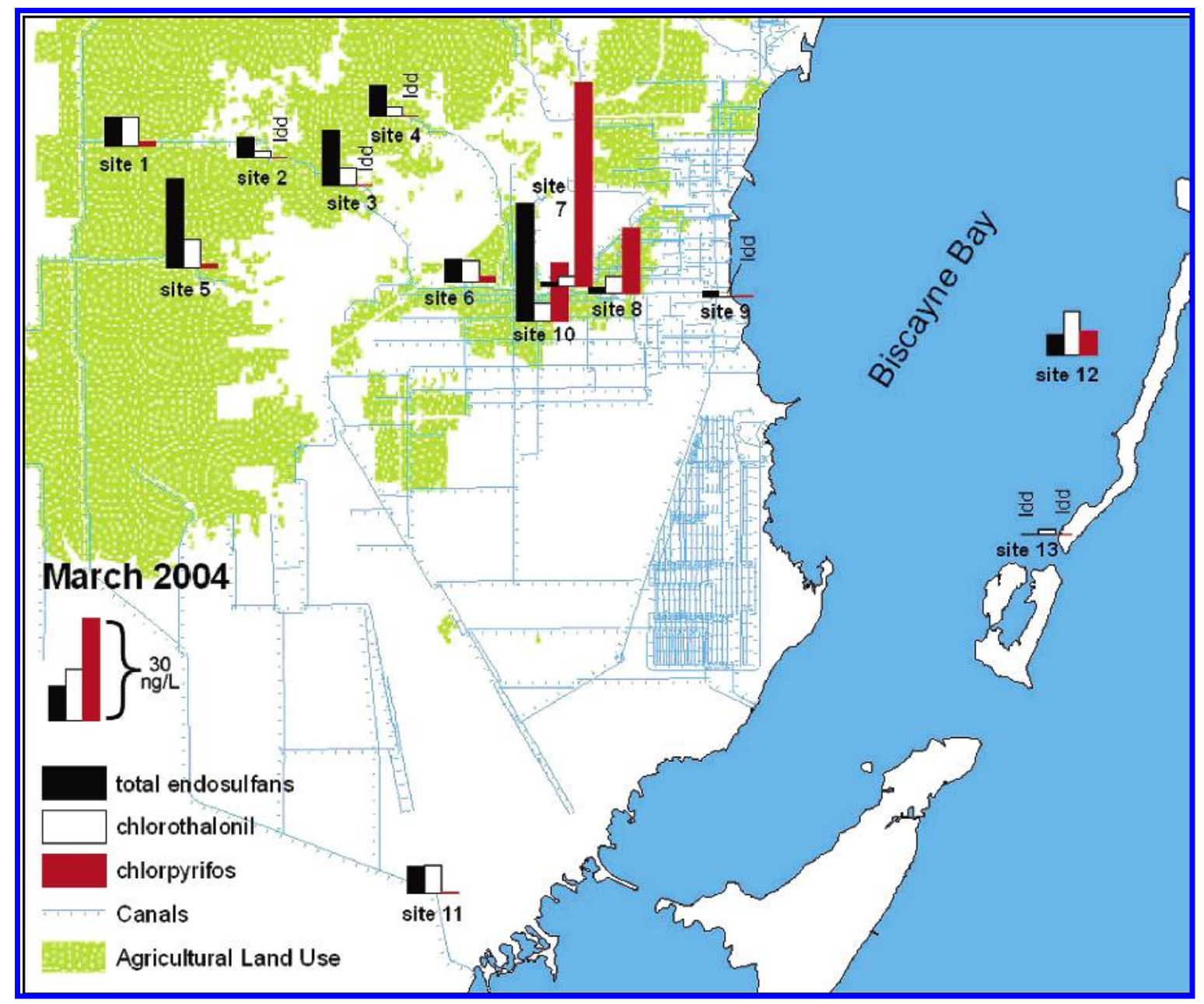

Figure 6. Spatial variation of the insecticides endosulfan, chlorothalonil, and chlorpyrifos for March 2003.

declined over the past 20 years at a rate of $\sim 230$ ha per year. Specifically, the area of land devoted to tomato production dropped from nearly 4500 ha per season in the mid-1980s to $\sim 1500$ ha in 2001 (21). Assuming the recommended manufacturer application rates for endosulfan were followed, estimated usage on tomatoes has declined by a factor of 3 (nearly 6000 $\mathrm{kg}$ of active ingredient/growing season) in South Florida.
Lower concentrations of chlorpyrifos and chlorothalonil observed by Scott et al. indicate that their stations, generally south of this study area, may have been further removed from sources. In an NOAA-USDA cooperative study conducted in December 1999, atrazine, chlorpyrifos, and metolachlor were measured in water samples from drainage canals of South Florida ranging in concentration from 7.9 to $29.4 \mathrm{ng} / \mathrm{L}$, from 


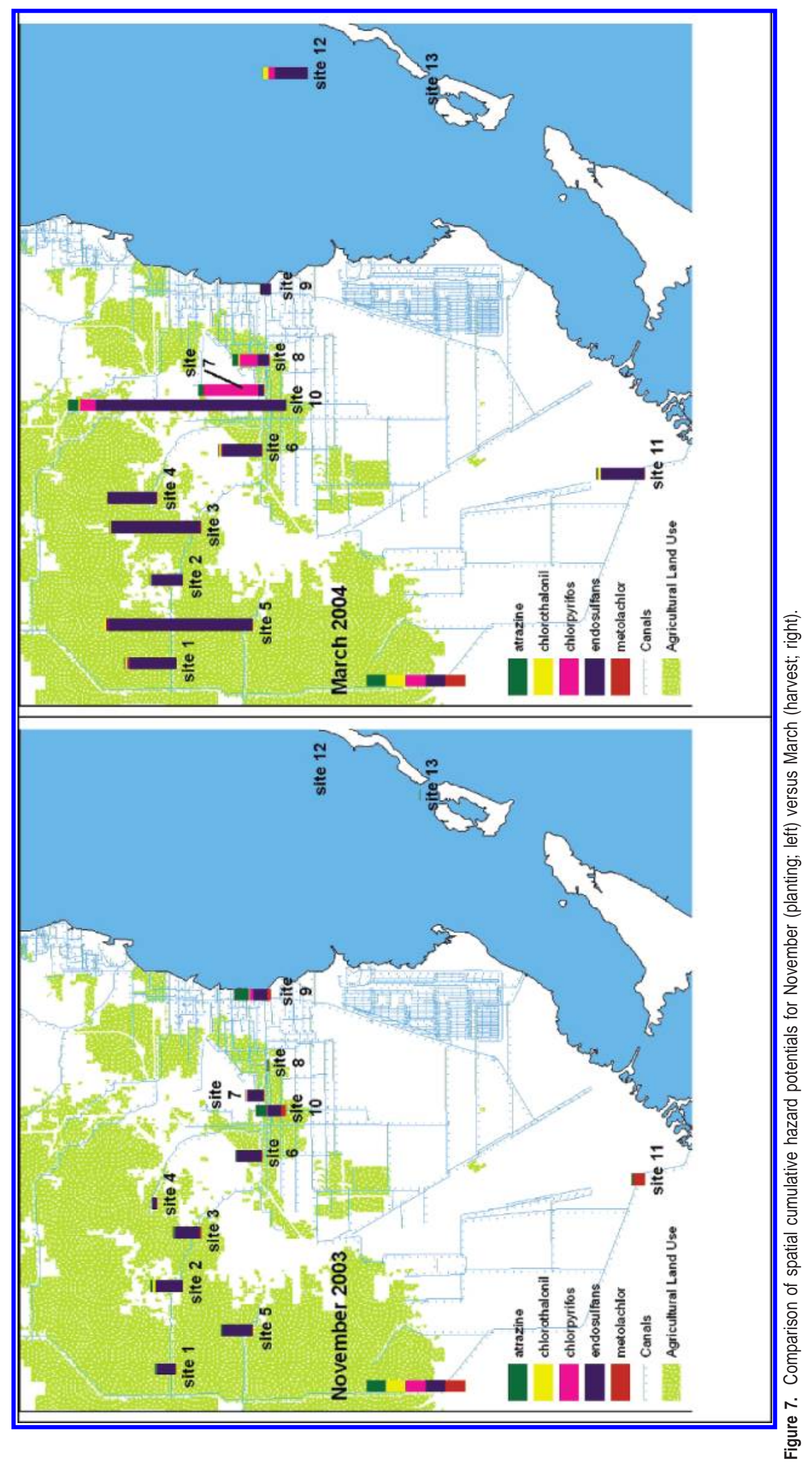


Table 4. Major South Florida Crops and Usage of the Five Most Commonly Detected Pesticides in This Studya

\begin{tabular}{|c|c|c|c|c|c|}
\hline \multirow[b]{2}{*}{ crop } & \multicolumn{2}{|c|}{ herbicides } & \multicolumn{2}{|c|}{ insecticides } & \multirow{2}{*}{$\frac{\text { fungicide }}{\text { chlorothaloni }}$} \\
\hline & atrazine & metolachlor & chlorpyrifos & endosulfan & \\
\hline bean, snap & & $x$ & & $x$ & $\mathrm{X}$ \\
\hline cabbage & & $x$ & $x$ & $x$ & $x$ \\
\hline corn & $x$ & $x$ & $x$ & & \\
\hline cucumber & & $x$ & & $x$ & $x$ \\
\hline pepper & & $x$ & & $x$ & $x$ \\
\hline squash & & $\mathrm{X}$ & & $x$ & $x$ \\
\hline tomato & & $x$ & & $x$ & $x$ \\
\hline watermelon & & & & $x$ & $x$ \\
\hline
\end{tabular}

a Pesticide use data from USDA-NASS (21).

5.2 to $11 \mathrm{ng} / \mathrm{L}$, and from 2.5 to $119 \mathrm{ng} / \mathrm{L}$, respectively (6). With the exception of metolachlor, these concentrations are generally lower than those found in the current study, but they represent only one sample collection time point at multiple sites. Although chlorothalonil and endosulfan were not detected in the Key et al. study, this is likely due to higher detection limits for these chemicals using an ion-trap GC-MS instrument. Limits of detection in the Key et al. study were $3.1 \mathrm{ng} / \mathrm{L}$ for chlorothalonil, $9.4 \mathrm{ng} / \mathrm{L}$ for $\alpha$-endosulfan, and $18.8 \mathrm{ng} / \mathrm{L}$ for $\beta$-endosulfan and endosulfan sulfate as compared to a $0.2 \mathrm{ng} / \mathrm{L} \mathrm{MDL}$ for these compounds in the current study (Table 2).

Spatial and Temporal Distribution of Pesticides. Corn is generally grown east of site 6 , and higher concentrations of atrazine, a corn herbicide, were generally observed at site 6 on each of the seven sampling trips with the exception of March 2003, when atrazine concentrations of 81 and $47 \mathrm{ng} / \mathrm{L}$ were found at sites 1 and 5, respectively. Atrazine was found in lower concentrations at sites 1-5 where vegetables (tomato, pepper, snap bean, and squash) were the predominant crops. Ornamentals are produced near sites $6-8$ in addition to corn. Very little atrazine was found in the remote locations or at the control site (Figure 3). The lowest concentrations of atrazine were observed during the middle part of the growing season, whereas the highest concentrations were observed in the beginning, although mean concentration in each month did not vary (Figure 4). Not surprisingly, a similar analysis of metolachlor concentrations revealed no discernible trend. This indicates either remote or multiple sources in the region as this product is used on all of the major crops in this area except watermelon (Table 4) (22).

Temperatures and humidity begin to rise toward the end of the growing season, increasing insect and fungal pressures. As a result, increased insecticide and fungicide (e.g, chlorothalonil, chlorpyrifos, and endosulfan) use would be expected to protect the harvest. Figure 5 indicates that chlorpyrifos and endosulfan concentrations were highest in the latter part of the growing season. Furthermore, chlorpyrifos is primarily used on corn, whereas endosulfan is used on other vegetables. This spatial difference is shown in Figure 6, where higher concentrations of chlorpyrifos are observed at sites 10 and eastward, and, concomitantly, endosulfan is more likely to be found west of site 10 . Although chlorothalonil was frequently detected $(82 \%)$, no discernible trends were observed. This may be a function of its fairly rapid degradation rate in soil, $t_{1 / 2}=0.5-3.5$ days (23), following application as compared to the reported hydrolysis half-life of 49 days (24).

Evaluation of Potential Risk to Aquatic Organisms. South Florida is a critical wildlife area as well as being an intensely cultivated region. A preliminary evaluation of potential risk to aquatic organisms was conducted using measured pesticide concentration data. A hazard rating system was developed that uses subcoefficients calculated for a number of pesticides to rank the potential impact of the pesticides on aquatic systems $(25,26)$. The coefficients are a function of toxicity of the pesticide to fish and crustaceans, bioconcentration potential represented by the octanol-water partition coefficient $\left(K_{\mathrm{ow}}\right)$, and soil half-life (Table 3). Endosulfan has by far the highest coefficient value at 42.8 , followed by chlorpyrifos at 7.18 . The remaining three compounds display much lower potential risk $(<2.6)$. A relative comparison of potential toxicity from various pesticides may be obtained by multiplying the coefficient by the observed concentration.

The coefficients were multiplied by observed concentrations for each of the five pesticides at each site at the beginning and end of the growing season. These values were used to estimate the potential risk associated with pesticide use. The cumulative values for each site are shown in Figure 7. Although atrazine was present at the highest concentrations, endosulfan presents a much larger hazard to aquatic organisms. The toxicity contribution from endosulfan increases in magnitude toward the end of the growing season with heavier insecticide usage and higher observed concentrations (March 2004). Chlorpyrifos also contributes to the potential toxicity in March at sites 7, 8, and 10. Thus, these data suggest the largest threat to aquatic organisms is not during planting but just prior to harvest.

Although this exercise provides some insight into the potential toxicity issues associated with pesticide use, more detailed studies to determine the length of exposure to high-risk pesticides, that is, continuous monitoring at key sites, not just grab samples, would provide a more complete picture. Risk calculations could also be carried out for other ecosystem components such as phytoplankton, submerged aquatic vegetation, wading birds, and aquatic mammals. In addition, the hazard potential calculations used here do not address synergistic interactions between pesticides, which may enhance the toxicity of certain pesticides, nor do they address the potential impact on the life cycle of particular species. Pesticide fate studies under soil, climate, and surface water conditions found in South Florida combined with advanced toxicological studies are required to accurately assess the risk from commonly used pesticides. Specially designed agricultural management strategies may be required to mitigate the off-site movement of pesticides and to protect especially sensitive species in the region.

\section{ACKNOWLEDGMENT}

We acknowledge the dedicated contributions from field technician Michael S. Gutierrez and collection volunteer Sally Mitchell.

\section{LITERATURE CITED}

(1) Perry, W. Elements of South Florida's Comprehensive Everglades Restoration Plan. Ecotoxicology 2004, 13, 185-193.

(2) Thayer, G.; Powell, A.; Hoss, D. Composition of larval, juvenile, and small adult fishes relative to changes in environmental conditions in Florida Bay. Estuaries 1999, 22, 518-533.

(3) Porter, J. W.; Meier, O. W. Quantification of Loss and Change in Floridian Reef Coral Populations. Am. Zool. 1992, 32, 625640.

(4) Water Resources Development Act of 2000 (WRDA2000). Public Law 106-541 of the 106th Congress, Title VI, Section 601. Dec 11, 2000. Government Printing Office: Washington, DC, 2000; available through http://www.evergladesplan.org/ wrda2000/wrda.cfm. 
(5) Scott, G.; Fulton, M.; Wirth, E.; Chandler, G.; Key, P.; Daugomah, J.; Bearden, D.; Chung, K.; Strozier, E.; DeLorenzo, M.; Silvertsen, S.; Dias, A.; Sanders, M.; Macauley, J.; Goodman, L.; LaCroix, G.; Thayer, G.; Kucklick, J. Toxicological Studies in Tropical Ecosystems: an Ecotoxicological Risk Assessment of Pesticide Runoff in South Florida Estuarine Ecosystems. $J$. Agric. Food Chem. 2002, 50, 4400-4408.

(6) Key, P.; Fulton, M.; Harman-Fetcho, J.; McConnell, L. Acetylcholinesterase Activity in Grass Shrimp and Aqueous Pesticide Levels from South Florida Drainage Canals. Arch. Environ. Contam. Toxicol. 2003, 45, 371-377.

(7) Fish, J. E.; Stewart, M. Hydrogeology of the Surficial Aquifer System, Dade County Florida; Water-Resources Investigations Report 90-4108; U.S. Geological Survey: Tallahassee, FL, 1991; $56 \mathrm{pp}$, available at http://sofia.usgs.gov/publications/wri/90-4108/.

(8) Shinde, D.; Savabi, M.; Nkdei-Kizza, P.; Vazquez, A. Modeling Transport of Atrazine Through Calcareous Soils from South Florida. Trans. ASAE 2001, 44 (2), 251-258.

(9) Lehotay S. J.; Harman-Fetcho, J. A.; McConnell, L. L. Agricultural pesticide residues in oysters and water from two Chesapeake Bay tributaries. Mar. Pollut. Bull. 1998, 37 (1-2), 32-44.

(10) Liu, B.; McConnell, L.; Torrents, A. Herbicide and Insecticide Loadings from the Susquehanna River to the Northern Chesapeake Bay. J. Agric. Food Chem. 2002, 50, 4358-4392.

(11) EPA. National Primary Drinking Water Regulations; last updated on Wednesday, May 26th, 2004; http://www.epa.gov/safewater/ mcl.html\#mcls.

(12) Miles, C.; Pfeuffer, R. Pesticides in Canals of South Florida. Arch. Environ. Contam. Toxicol. 1997, 32, 337-345.

(13) Florida Agricultural Statistics Publications. Florida Facts-06/ 11/03: Vegetable, Field Crops, and Livestock; 2003; http:// www.nass.usda.gov/fl/rtoc0cr.htm.

(14) Florida Agricultural Statistics Publications. 2002 Census of Agriculture-State and County Profiles for Miami-Dade County; 2003; http://www.nass.usda.gov/fl/rtoc0cr.htm.

(15) Lu, F. C. A review of the acceptable daily intakes of pesticides assessed by the World Health Organization. Regul. Toxicol. Pharmacol. 1995, 21, 351-364.

(16) Pfeuffer, R.; Rand, G. South Florida Ambient Pesticide Monitoring Program. Ecotoxicology 2004, 13, 195-205.

(17) Pfeuffer, R.; Matson, F. Pesticide Surface Water and Sediment Quality Report: November 2002 Sampling Event; The South Florida Water Management District: West Palm Beach, FL, 2002.

(18) Pfeuffer, R.; Matson, F. Pesticide Surface Water and Sediment Quality Report: March 2003 Sampling Event; The South Florida Water Management District: West Palm Beach, FL, 2003.

(19) Pfeuffer, R.; Matson, F. Pesticide Surface Water and Sediment Quality Report: May 2003 Sampling Event; The South Florida Water Management District: West Palm Beach, FL, 2003
(20) Pfeuffer, R.; Matson, F. Pesticide Surface Water and Sediment Quality Report: October 2003 Sampling Event; The South Florida Water Management District: West Palm Beach, FL, 2003.

(21) Degner, R. L.; Stevens, T. J.; Morgan, K. L. 2002 Miami-Dade County Agricultural Land Retention Study: Summary and Recommendations; Florida Industry Report 02-02; Florida Agricultural Market Research Center, Institute of Food and Agricultural Sciences, University of Florida: April 2002; http:// agmarketing.ifas.ufl.ed $u / d$ lfiles\%5CSummary.pdf (verified March 14, 2004)

(22) U.S. Department of Agriculture, National Agricultural Statistics Service. Ag Ch 1 (03)b, Agricultural Chemical Usage, 2002 Vegetables Summary; July 2003; http://usda.mannlib.cornell.edu/ reports/nassr/other/pcu-bb/agcv0703.txt.

(23) Potter, T. L.; Wauchope, R. D.; Culbeath, A. K. Accumulation and decay of chlorothalonil and selected metabolites in surface soil following foliar application to peanuts. Environ. Sci. Technol. 2001, 35, 2634-2639.

(24) U.S. EPA; Reregistration Eligibility Decision (RED): Chlorothalonil, Document EPA 738-R-99-004, April 1999; http:// www.epa.gov/oppsrrd1/REDs/0097red.pdf.

(25) Pait, A. S.; DeSouza, D. R.; Farrow, D. Agricultural Pesticides in Coastal Areas: A National Summary; Strategic Environmental Assessments Division, ORCA/NOS/NOAA: Rockville, MD, 1992; 112 pp.

(26) Ott, W. R Environmental Indices: Theory and Practice; Ann Arbor Science Publishers: Ann Arbor, MI, 1978; 371 pp.

(27) U.S. EPA. Interim Reregistration Eligibility Decision (RED): Atrazine, Case 0062, Jan 2003; http://www.epa.gov/oppsrrd1/ REDs/atrazine_ired.pdf.

(28) U.S. EPA. Reregistration Eligibility Decision (RED): Chlorpyrifos, Document EPA 738-R-01-007, Feb 2002; http://www.epa.gov/oppsrrd1/REDs/chlorpyrifos_ired.pdf.

(29) U.S. EPA. Reregistration Eligibility Decision (RED): Endosulfan, Document EPA 738-R-02-013, Nov 2002; http://www.epa.gov/oppsrrd1/REDs/endosulfan_red.pdf.

(30) U.S. EPA. Reregistration Eligibility Decision (RED): Metolachlor, Document EPA 738-R-95-006, April 1995; http:// www.epa.gov/oppsrrd1/REDs/0001.pdf.

Received for review December 28, 2004. Revised manuscript received March 31, 2005. Accepted April 1, 2005. Mention of specific products or supplies is for identification and does not imply endorsement by the U.S. Department of Agriculture to the exclusion of other suitable products or suppliers.

JF047803G 